University of London. All his spare time was given to teaching literature at the Mansfield House University Settlement in Canning Town, where he found himself becoming so absorbed by the social problems of the neighbourhood that, in 1912, he became secretary to the Settlement, a post which he held until 1919. This experience coloured his whole life and determined his future work for, on removing to the Settlement, he was immediately plunged into the distress connected with a great dock strike, and his first book, "Casual Labour at the Docks" (1916), was based on material collected in Canning Town. The conditions with which he was brought into such close contact convinced him of the need for a careful study of social organization if any constructive reform was to be achieved and this remained the chief preoccupation of his life.

Further experience, first as social studies secretary of the Student Christian Movement, later as lecturer in social science to the Lancashire and Yorkshire Congregational Union, gave Dr. Mess greater opportunities for gathering detailed knowledge of social conditions and, after a period at the London School of Economics during which he wrote his "Factory Legislation and Administration", he began the work which was to prove his most outstanding achievement. In 1925 he was appointed director of the Bureau for Social Research for Tyneside and later director of the Tyneside Council of Social Service, and for ten fruitful years be identified himself with the life of a region that was suffering all the incalculable misery of prolonged industrial depression. True to his belief in the need for greater knowledge, he was not oontent to initiate and foster innumerable efforts to preserve and develop the community life of the area ; he also conducted a social survey, published as "Industrial Tyneside", which is a model of its kind.

In 1935 Dr. Mess was appointed reader in sociology at Bedford College (University of London), and for the first time had the leisure to devote himself more fully to research; but he was by no means cut off from other activities. He sat on many advisory bodies, acted as University Extension lecturer and gave many broadcasts, the most notable of which was a series of talks on "Social Groups in Modern Eng. land", which was later published in book form. In 1942 the College gave him part-time leave of absence to enable him to act as director of studies to the National Council of Social Service, and at the time of his death he was engaged in a number of extremely important inquiries, in which the combination of sociological technique with his wide knowledge of contemporary economic and social conditions was of inestimable value.

By temperament, Mess belonged to that breed of Nonconformist Liberal whose contribution to social reform in Great Britain has been so striking and, indeed, through his mother's family he had direct links with the early Independents. He was a sincere Christian with a profound belief in the dignity and powers of the common man, given the right social environment. It was from this faith that all his work drew its inspiration. As a sociologist, he was just beginning to see his way clear, and there is no doubt that, had he lived, his wide knowledge and humane sympathies would have enabled him to make a real contribution to this youngest of university disciplines. English sociologists can ill afford to lose so valuable a member of their small band.

GERTRUDE WIILIAMS.

\section{Major H. J. L. Beadnell}

Hugh John Llewellyn Beadnetl died suddenly on January 2. He was born in 1874 and was educated at Cheltenham College, King's College (London) and the Royal College of Science. He had a long and vigorous career, and his name is linked above all with the geology and water resources of the Libyan Desert. He joined the Geological Survey of Egypt in 1896, and his early work included the geology of the Abu Roash dome near the Pyramids of Giza : soon, however, he was sent westward to the Libyan oases of Farafra, Dakhla, and Baharia, and then to the Faiyum. His report on the last of these was a remarkable achievement, and it provided a solid basis for the specialized work of those who followed more than twenty years later with advantages of transport and equipment which were unheard of in his day. From his Faiyum investigations, moreover, came the discovery, in which $\mathrm{C}$. W. Andrews of the Natural History Museum shared, of the highly important Eocene and Oligocene mammalian remains (Eosiren, Moeritherium, Palæomastodon, Arsinoitherium and others) which are known to palæontologists throughout the world. In 1905 he investigated the relations of the Eocene and Cretaceous beds between Esna and Aswan, in Upper Egypt.

In 1906 Beadnell's interest in the Libyan oases took him into the scheme for the reclamation of Kharga oasis, and he left Egyptian Government service. He was concerned with this project, which did not realize expectations, until 1910, and he published the well-known book "An Egyptian Oasis" in 1909.

The next phase of his life was varied, and typical of him. He went ranching in British Columbia (1912-15), enlisted in the Artists Rifles in 1916, served with the Egyptian . Expeditionary Force (1916-19), and completed his service with the acting rank of lieutenant-colonel: he was mentioned in dispatches and received the Order of the Nile. After the War he was engaged in the search for oil, was surveying in Central Sinai and on the Red Sea coast during 1921-25 (in Egyptian Government service once more) and wrote "The Geology of the Red Sea Coast between Qoseir and Wadi Ranga" (Petroleum Research Bulletin No. 13, 1924). Two years later his delightful book "The Wilderness of Sinai" was published.

In 1927 Beadnell roturned to official work in the Libyan Desert and for two years he was actively employed, especially with the work on wells in remote parts of the desert. Too little has been written of what he achieved in those two years and in his last period in the Libyan Desert, during 1930-32, when he was resident engineer of the Qattara Depression hydro-electric project of the Egyptian Government. The scheme aimed at running water from the Mediterranean to turbines at a site below sea-level in the depression.

From about 1932 Beadnell was seriously ill and spent much of his time in London : active still, he maintained his lifelong interests and took up gemmology. His last years were clouded by the death of one of his two daughters, then of his wife, who had been his companion since the early days in Egypt (they married in 1904). In 1940 he was engaged by the War Office with the rank of temporary major in the Royal Engineers, which he held at the time of his death.

In addition to his two books and to his official 
reports, Beadnell contributed to scientific publications, and especially to the Geographical Journal. He was awarded the Barlow-Jameson Fund of the Geological Society of London in 1904 and received the Cuthbert Peak Grant of the Royal Geographical Society in 1931 . K. S. SANDHORD.

\section{Dr. Birkett Wylam}

BrRketT WrLaM, chief inspector for Scotland under the Alkali, \&c., Works Regulation Act and Rivers Pollution Prevention Acts, died suddenly at his home in Edinburgh on January 15. While Dr. Wylam had not been in his usual vigorous health for some time, the news of his untimely death came as a shock to his many professional friends.

A native of County Durham, Dr. Wylam was a graduate of the University of Durham, where he took the degrees of B.Sc. in 1921, M.Sc. in 1922 and Ph.D. in 1925. He became an associate of the Royal Institute of Chemistry in 1924 and was elected to the fellowship in 1935. He was an active member of the Council of the Institute during 1938-40, and was a prominent figure in the Edinburgh Section, of which he was chairman. He also took an active interest in the Society of Chemical Industry. In 1936 he became a member of the Institution of Chemical Engineers.

Dr. Wylam began his professional career as research chemist to Morton Sundour Fabrics, Ltd., and later was research chemist and process manager at Scottish Dyes, Ltd. (I.C.I.), Grangemouth. He left this post to take up his official duties with the Department of Health for Scotland in 1931. During the War of 1914-18 he served with the Royal Garrison Artillery in France.

I have been privileged to know Dr. Wylam for some eight years, during the last five of which I have been his colleague. He was a delightful person to work with, always thorough, sympathetic and helpful. He was a fair man, his standards were high, and he was incapable of being mean. His chief interest was in doing things, and an idea had no sooner crystallized in his mind than the machinery was set in motion to effect its realization. He never sought praise ; it was sufficient for him to experience the pleasure of a job well done.
In his dealings with the chemical industry in the execution of his official duties he earned the respect of all as a competent chemical engineer, and he carried into this sphere his personal characteristics of fairness, high standards, and ever-readiness to belp. For reasons of national security I cannot give details of his war-time activities ; it is sufficient to say that his whole energy was directed into channels calculated to shorten the duration of the present conflict.

Dr. Wylam truly lived and enjoyed every moment of his life, at work, at home and at play. His hobbies were all constructive as well as artistic. He had a wide range of engineering and woodworking tools, which he put to no mean use. He was a keen photographer, a collector of commemorative medals, and a very wide reader. Science in Scotland has lost a man who, by virtue of his wide practical experience and acute mental alertness, was at his prime. To Mrs. Wylam and her children we offer our most sincere sympathy. JohN Hamilton.

WE regret to announce the following deaths :

Dr. L. H. Baekeland, the distinguished plastics chemist and inventor of 'Bakelite', on February 23, aged eighty.

Mr. H. H. Brindley, fellow of St. John's College, Cambridge, and during 1926-34 University demonstrator in zoology, on February 19, aged seventyeight.

Prof. J. W. H. Eyre, emeritus professor of bacteriology in the University of London, on February 17, aged seventy-four.

Prof. Yandell Henderson, professor of applied physiology at Yale University, on February 18, aged seventy.

Mr. J. Reid Moir, F.R.S., president of the Ipswich Museum, on February 24, aged sixty-four.

Prof. H. F. Newall, F.R.S., emeritus professor of astrophysics in the University of Cambridge, on February 21, aged eighty-six.

Dr. E. O. Ulrich, formerly geologist in the U.S. Geological Survey, known for his work in invertebrate palæontology, aged eighty-seven.

Mr. S. E. Winbolt, formerly of Christ's Hospital, Horsham, who was an authority on Roman antiquities in Great Britain, on February 16, aged seventy-six.

\section{NEWS and VIEWS}

\section{Edinburgh Medical Men and the Great Adventure}

THE spirit of adventure as it has been exemplified by graduates of the University of Edinburgh was the theme selected by Prof. James Ritchie for his 'Promotor's' address at the Medical Graduation at the University of Edinburgh last July. It was, Prof Ritchie pointed out, the Edinburgh medical graduate Mungo Park who discovered and traced the greater part of the course of the River Niger. Another medical student, Laing, discovered its source. Yet other Edinburgh medical men completed the Niger adventure, for Oudney discovered Lake Chad and Baikie led the last Niger expeditions sent out by the British Government. All these pioneers died in Africa. But, even before Park's day, men from the University of Edinburgh had been active in Africa. James Bruce re-discovered the sources of the Blue Nile, while Joseph Thomson, a pupil of T. H. Huxley, has been described as the last, and one of the most successful, of the great geographical pioneers in Africa. Other Edinburgh medical men have carried the spirit of adventure to geographical discoveries in India, Australia and America, and these men studied at the same time the natural history of the lands wherein they pioneered. On the seas the spirit of adventure is exemplified by Scoresby, the Whitby lad who became a world authority on the life of whales. To the Edinburgh naturalists Sir John Richardson, Harry Goodsir and John Macgillivray, the Franklin Arctic expedition owed much.

No doubt the graduates. of Edinburgh or of other universities will be interested to learn that Edward Forbes, who founded the science of oceanography, left that University in his ninth year as a medical student without a degree, to return fourteen years later to do brilliant work as its professor of natural history. Wyville Thomson, another medical, also left without a degree, but because his health was not 